\title{
Intended Fallacies: Lowered Horizons, Ideological Inversions and Employed Intimacy. Translating Judita Vaičiūnaitè's Early Poetry into Russian
}

\section{GINTARE் BERNOTIENE்}

\begin{abstract}
The case of the translations of Lithuanian poetess Judita Vaičiūnaite (1937-2001) early poetry into Russian clearly illustrates the damages an original literary text (and the author's institution) bore seeking to gain a statewide readership. In this article the Soviet translational practice of the 1960s is discussed as a phenomenon typical of Soviet literature when intentional rewriting, expurgation and ideological remakes of the authorial text were considered to be normal.

The lowered horizons when translating the minor nationality's original poetry, notable ideological inversions and the use of the source text in the most general scheme of the plot in Vaičiunaitë's early poetry translations into Russian, and even intimacy used in favour of ideological records marked not only the weakness and incompetence of amateur translators but also the pressure of the censoring institutions upon the author. The invisible chains of Soviet literary patronage demonstrated that the aesthetic value of the original and its translations for the publishing and propaganda industry of that time were of secondary importance. Wishing to spread their work to the wider circle of the Soviet readers and to strengthen the symbolic power, most often authors used to agree to the substitutions and editorial interventions into the authorial text. The interactions between the propagandist-educational character of the translations of that time and the artistic aims of the translational process in Soviet literary criticism were discussed later, after the revision of the Soviet heritage, evaluating the role of literature as a servant of the Soviet power machine.

The fact that Vaičiūnaitè publicly never mentioned her early poetry translations into Russian reveals her attitude towards the prevalent translational practice: it was negatory as well as instrumental. Having agreed with the imprints of the Soviet literary patronage on the translations of her texts, she took the step gaining personal legitimisation in the state-wide Soviet literary universe.
\end{abstract}

Keywords: Soviet Lithuanian poetry; poetry translation; ideology; Judita Vaičiūnaitè 
In the field of Russian culture the young Soviet Lithuanian poetess Judita Vaičiūnaite debuted quite early: first translations of her poems were published in 1960 in the printed media of the Soviet Union, when she was only twentythree years old. In 1964, while celebrating the $250^{\text {th }}$ anniversary of the birth of the Lithuanian literary classic Kristijonas Donelaitis, she was travelling with the members of Soviet Lithuanian Writers Association to Moscow: in the photograph she is standing next to Vacys Reimeris, who was her patron in real life as well. From the objective point of view, a young recently debuted poet had a real creative potential. In the $20^{\text {th }}$-century Lithuanian literature she is still seen as one of the most talented poetesses who together with poets Sigitas Geda, Jonas Juškaitis, Marcelijus Martinaitis were initiating the modernist revolution in Lithuanian poetry. However, from all of the mentioned modernists, only Vaičiūnaitë's book was published in Russian as early as 1964 . $^{1}$ The early translations of her poetry into the Russian language clearly reveal how the national representation of a "small" nation's poet was perceived, disregarding the author's rights to her work as a meaningful unit, and what freedom of activity had the ideological institutes for translation supervision and control in the Soviet Union in the 1960s.

When translating the literature of "small nations" into the Russian language, the aim to "be as loyal to the original as possible" was achieved differently. In the USSR, the loyalty to the original and seeking for maximum comprehension were important only from one perspective, i.e., preparing to publish the translations of the dominant Russian culture, and creating and spreading the new general Soviet literature canon. The examples of translating small nations' literature illustrate the unrevealed, complicated, false translation authorships: a stolen translation or adapted translation on the

1 In fact, the publication of poems in Russian and especially by central publishing houses by the elder generation of Soviet Lithuania's poets was accepted as their formal acknowledgment by the power structures and the marker of their stability in the Soviet literary canon. For the first time in 1981 several poems of Martinaitis were included in a selection of poetry by canonised Soviet Lithuania's authors (Ten' solnca ... 1981). The inclusion of Martinaitis's poems in this collection was determined firstly by the translator's choice. Even the poetry collection by Martinaitis Порог (Martinajtis 1981), released in Vilnius, did not show the steady circulation of Martinaitis's poetry in the central literary field. And only the huge success of his cycle of poems "The Ballads of Kukutis" did strenthen the position of Martinaitis and determined the publication of the cycle by the prominent publishing house "Советский писате ь” in 1983. Another prominent Lithuanian poet Sigitas Geda was given access to the wide Soviet reading audience 25 years after Vaičiūnaitè's debut (see Gjada 1986; 1989). 
Intended Fallacies: Lowered Horizons, Ideological Inversions and Employed Intimacy

basis of the existing classic literature model (Mitaite 2015: 100-102) ${ }^{2}$, and the cases of arbitrary expurgation and rewriting without the author's knowledge and permission, i.e., actions that from the perspective of the work of art and authorship institutions were possible only when the literature control was centralized.

André Lefevere, theoretician and historian of the comparative translation, in his study Translation, Rewriting and the Manipulation of Literary Fame (1992), offered to perceive any translation practice that is directly related to the creation of the canon (especially in the totalitarian societies) as an intentional rewriting when the adapted text is adjusted to the ideological or poetic aims (usually both at a time) of the target language culture (Lefevere 1992: 2). The examples of Vaičiūnaitë's translations correspond to this generalization.

\section{A calculated debut}

The first translation of Vaičiūnaitè's poetry in the Russian language was published together with her poetry collection "Aquarelles of Spring" in 1960 in the prestigious literature and society newspaper $\Lambda$ итературнал газета (the poem "Shadows on Snow" translated by Ivan Fedorin, Vajčjunajte 1960), in newspapers Орловскал правда and Комсомольскал правда (the poem "If You Think I Am a Ray of Sunshine" translated by Veronika Tušnova) and in the shortly-published USSR Writers' Association newspaper $\Lambda$ umepamypa и жизнь, which in 1962 was reorganised into a weekly newspaper $\Lambda$ umepaтурная Poссия (translation by S. Dorizo from the cycle "For the Only City"). Vaičiūnaite debuted in the republican press around $1952^{3}$, and her first collection Life is Calling was planned for publishing in 1959, but the book was criticised and scattered due to the author's disloyal behaviour to the government: when finishing her Lithuanian studies at Vilnius University, she refused to join the Young Communist League. However, in 1960, among a series of the "First Book" debutants, there was Vaičiūnaitë's book which, as the poetess herself later sincerely admitted: "was worn out by myself and the needs of time, as well as others" (Vaičiūnaitè 1992: 194).

2 Donata Mitaitè in her article "Sovietmečio literatų ryšiai” ('Communication of Soviet Writers') describes how prominent Soviet Russian poets were translating and rewriting (under the canon of Russian literature) the poetry of Soviet Middle Asian republics.

3 "Nekrasovui" ('To Nekrasov', Vaičiūnaite 1952). 
BERNOTIENÉ

\section{First book of translations}

Before the appearance of the first poetry collection in the Russian language, the translations of Vaičiūnaite's poems were published in the Lithuanian and Soviet Union's press (Vajčjunajte 1962a-b; 1964a-e), and her first collection Стихи was released in 1964 in 6,000 copies. It was prepared for the press by one of the biggest Soviet publishing houses Молодая гвардия, which was working in the fields of national education, literature popularisation and the community's political education. The publishing houses were specialised in preparing translations of foreign and Soviet bloc countries' literature and publishing the series of "Библиотечка избранной мирики”, thus, a 72-pages-long soft cover publication of Vaičiūnaitès poetry translations with simple fretworks by Marina Kozlovskaja, should have lived up to the readers' expectations.

However, the aims of the publishers had first of all the introductory and propaganda character. Introduced as an acknowledged poet in the republic, from the translations of her poems Vaičiunnaite seemed to spread not only "optimism, emotionality and exceptional imagery" (Editor's note 1960: [2]). Half of the chapters of the book, from eight in total, with local Lithuanian colouring and softened, subtly revealed feelings contrasted with the international themes (and even open criticism of the capitalist world) of other chapters that were stressed by title of the chapter, which is the modified title of Vaičiūnaitës book Per sauleta gaubli - По ту сторону глобуса ('Across the Sunny Globe - On the Other Side of Globe') that was planned to be published in Lithuanian.

Vladimir Sergejev, who translated most of the poems, allows himself to omit several lines or even stanzas, and in other cases, on the contrary, to create the overall poem's imagery by adding unmotivated extensions in lines and even stanzas (as in the poem "Tank"); he is translating disregarding the author's metaphors, very precise, realistic details of imagery, i.e., the layer which makes the core of Vaičiunnaite’s poem. There are numerous lexical discrepancies (whitewashed apple trees becomes домики (little houses) (5), thaw - кето (summer) (6), cube - Аиск (disk) (10), sleeplessness - лень (laziness) (14)), which shows that the translator perceived the original not as a solid autonomic poetic structure, but as a material used for a usually very approximate, not literal, but in comparison to the original, rather faceless, poor imitation that is worn out by the standardised phrases and popular thinking. In the translation practice of the $19^{\text {th }}$ century, the term imitation was often used for freely recreated texts. 
Intended Fallacies: Lowered Horizons, Ideological Inversions and Employed Intimacy

But what was the size of this modest red cover book of Vaičiūnaitë's translations in the ocean of Soviet literature? From the perspective of Lithuanian literature that flowed into the Union's literature pool that was stylistically and aesthetically unequal, the most important and long-prepared burst into the Soviet arena was the poem-project by Eduardas Mieželaitis "A Man" that was retrospectively presented by the author himself as an absolute success and a certain attempt to "westernize" Soviet culture. However, in the Moscow literary orbit, even Mieželaitis and Nazim Hikmet were called halfEuropean and half-Asian provincials (Samojlov 1995: 346); thus, a young, just starting Lithuanian poet could not be called anything else by the Soviet literary "wolves" but a provincial in the Moscow-centered universe. This explains the preparation for publishing, translation, illustration and other literary patronage aspects of her publication.

\section{Journalist's translations}

The thirty-eight poems from the collection (out of fourty-six) were translated by Sergeiev who was born in 1930, had finished courses of Translation from Bulgarian and Journalism at the Leningrad University and was working as a journalist in Magadan and Barnaul. Why was this translator appointed to translate Lithuanian poetry?

The first collection of poems Вместе с вами by Sergeiev was published in 1956 in Magadan; it made a big impression on one influential poet, the editor of the journal Новый мир, Aleksandr Tvardovski (Ogryzko 2007). The work with the absolutely different style of modern "western" lyrics was given to Sergejev, who until then was working as a journalist and successfully translating poetry from Chukotka and who was sent to the higher literature courses in Moscow in 1960-1962, due to Tvardovski's trust. Unfortunately, for Vaičiūnaite, the readers will not find in his translations the sensitive, subtle delicacy that is softly melting, the random visual allusions, the alliterating framework of stanzas, the modern syncoptic rhythm or experimental breaking of lines. The translator was working not with the form of the poem, but with the content in the most primitive sense of the word.

Sergejev's work was sarcastically characterised by the litterateur from Altai Vladimir Sokolov ${ }^{4}$ :

4 Vladimir Sokolov graduated from the Maksim Gorky Literature Institute in Moscow in 1980. He is a translator from English, German, Latin. He met Sergeiev in the Altai publishing company where he got a job as an editor. 
Themes of his poetry are very unoriginal: love and friendship, war and peace, good and evil and everything, as with many Soviet poets, autobiographically spiced, and still so boring and banal. As a feature of his poetry there should be mentioned the highlighted sense of duty of a Soviet patriot, communist, journalist. (Sokolov 2006)

The individuality of the translator presupposed his translation strategies; most of his translated poems were left without rhyme; the descriptive function prevailed in the translation, and Vaičiūnaitè's subtle metaphors were reduced to approximate comparisons.

For example, in Vaičiūnaitë's poem "Pine" that has already become her visiting card, Sergejev does not recognise cubism as well as the vivacious chopped rhythm of sentences in the first stanza:

\begin{tabular}{|c|c|}
\hline Rankas po galva. Mèlyna pušis & [Hands under your head. Blue pine - \\
\hline Kaip raketa, kaip mèlyna detalè. & like a rocket, like a gothic detail.] \\
\hline Закину я руки за голову & [I will put my hands under the head \\
\hline И ввысь посмотрю & And look up. \\
\hline НаАо мной, & Above me, As if out of blue tin \\
\hline Как буАто из синего омова & As if out of blue tin \\
\hline Сосна, уходящая в зной. & Pine is leaving in heat. $]^{5}$ \\
\hline
\end{tabular}

In this translation, the created dynamics of the image is replaced by the coherent and descriptive narrative, the enclosed rhyme is replaced by alternate rhyme. The unexpected perspective into which Vaičiūnaite throws her reader is revealed in logical sentence steps that grow into additional lines which try to hide the distortion of the content and omitted 7 (from 16) lines of the original. Vaičiūnaitè's attempt to complicate the realistic image of nature, the pine trunk that grows from the ground up to the clear sky, to render it in an unexpected play of forms and geometric drawing that is clearly alluding to the intertextuality of modern $20^{\text {th }}$-century art (pine as an arrow to the cube of sun) is devastated. Vaičiūnaite's intimate intonation is influenced by the changing sight direction (to pine, planet, sun and dress as a metonym for women), and the heartwarming perception of this fragile moment understood as gift. There is no final mark of a gift in translation, most probably it would not correlate with the much more optimistic image of the conquered space and the image of the old planet Earth. Neither the

\footnotetext{
5 Literal translation by G. Bernotienè.
} 
Intended Fallacies: Lowered Horizons, Ideological Inversions and Employed Intimacy

alliteration saules strofa, strèle, stebuklą (sun's stanza, arrow, miracle) which could easily be converted into the Russian language (солнце, строфа, стрела), nor the bright contrasting colours recalling cubist canvasses or the exceptional sensitivity of the light in space are retained in the translation. The realistically thinking translator, for whom the formal acoustic and visual elements of the poems are not a challenge, focuses on the fluent rhyming. Working with this poem the translator does not make an effort to render the combination of the sophisticated, indirect rendering of the visual perception, and the elaborate, abstract vocabulary of Vaičiūnaitè verse, but gives the poem additional ideological accents corresponding the official Soviet rhetorical clichés which are missing in the original. Sergeiev's disregard for the unusual construction of the poetic image which is characteristic of Vaičiūnaitè and determines her poetic innovations in the field of Lithuanian poetry led him to oversimplification.

\section{Ideological inscriptions}

The opinions of contemporary critics on the translation and ideology issue differ. Some scholars ignore this issue and state that, in a general sense, it is possible to suspiciously search for the manifestations of ideology, government and power in almost all human situations. Others, on the contrary, believe it is important and base the essence of this issue on empirical data; they discuss whether the translation is controlled by anyone, how something that is translated, removed or eliminated is evaluated by one or the other socium, and finally, what is omitted, added, modified in order to control the message that the translation is sending (Fawcet 2000: 107). On the final page of Vaičiunaitè's poems' publication in the Russian language, as in all the books that were published during the Soviet period, there is a mark "Подп. к печати 8/ V 1964" (signed for publication) which is a direct proof that the permission was censored by Glavlit ${ }^{6}$; thus, it has passed the political and ideological control. The essential changes in the authors' texts that were made by Sergeiev (poems “To Unknown Kabiria”, "Hiroshima”) allows to investigate his translations as examples of ideological marks and insertions. For example, the translator translates only the second half of the poem "Hiroshima" that is not singled out by the author graphically or can be claimed as an independent,

6 Glavlit (ГАавное управление по охране государственных тайн в печати при СМ CCCP: General Directorate for the Protection of State Secrets in the Press under the Council of Ministers of the USSR) - the official censorship organ in the Soviet Union. 
BERNOTIENE

meaningful unit, regardless of the fact that the first part of the poem that stresses the intimate addressing of the situation is essential for the whole poem. Even though the number of lines in the original and its translation should not be chosen as the indicator of equivalence, twelve omitted lines from the first part of Vaičiūnaitës poem are compensated for by the equal number of lines created by the translator, and this is the only formal excuse for such an addition. The long translator's addition is connected to the unrhymed original through rhyme, whereas three rhythmic anaphora steps (Только светитсл; Только крик; Только взгляд - Only light; Only scream; Only look) and emotional talking of the translator recalling his experiences even makes the expurgated poem, which in translation provides dull statistics, more vivid. To the original lines about the world as a closed fan, i.e., the ended life (a beautiful Eastern metaphor), the translator puts the not so subtle references, the literal lexis of military death, pain, mourning, the nation's funeral processions, explosions, revenge and repayment. In the passage added by the translator, the things that are implicit in Vaičiūnaitè's poem are written explicitly: the atomic explosion, suffering and death. The main stress is transferred to the militant pathos that is enlarged by the power of suffering, but this pathos emotionally, politically and ideologically lays the foundation for the clear but not directly mentioned confrontation between the cold war countries (USSR and USA).

During the period (Vaičiūnaitè's poems were translated only five years after their writing), a similar system of taboo and normative themes do not position the source and target texts as radically different. There are original texts that have been marked by the author herself" (the theme of socialist construction in the poem "Mountain Road Worker", the theme of war in the poems "Twenty Millions", "Hiroshima”, “Tank”, the Jewish/German theme in "Ana Frank"). There are poems that are a little overlapping the boundaries of what was allowed by the "socio-realistic" codex. Vaičiūnaitè had the courage to establish a new purpose in her poetry (to legalize intimate feelings, to expose her connection with aesthetic literature and other arts, the historical themes) that was not recognised by the translator and was perceived by him as an unimportant poetic message for those who are looking for more "noble" themes.

Poet Juozas Nekrošius who was senior than Vaičiūnaite by two years and excelled her as a member of the Communist Party in the annotation of her poems the collection Kaip žalias vynas (Like a Young Wine, 1962) wrote: "Vaičiūnaitè remembers the unhealed wounds of the war, and millions of people that were victims of the war." This political emphasis was necessary to prove the loyalty of young author to the Soviet regime. (Nekrošjus 1962) 
Intended Fallacies: Lowered Horizons, Ideological Inversions and Employed Intimacy

The propagandist nature of the collection and ideological engagement have already been mentioned; thus, the following example aims at illustrating how even intimacy was used for ideological purposes. In the chapter "Венгерские стихи" ('Hungarian poems'), there are three poems from the cycle "Miestas - žvaigždèlapis” ('City is a Starmap'), which were published in 1963 in Pergale (Vaičiūnaitè 1963), that are far from neutral and have never been included in any author's collections in Lithuanian. Based on travelling impressions, the cycle has an intimate character, not peculiar to the reportage theme: everything that is visited in a foreign country is described from the perspective of soft, personal experiences in the seven-poem cycle, as if curling into a cosy cocoon of feelings: Tegu rūdija rūsiuose - karaliu sarkofagai, / Tegu rūdija aikštèse - kaladès maištininku galvai, / Tegu rūdija tuneliuose - grandinès nuo didžiuliu tiltu ... // Ař tik kartoju - gelsvas tavo namas [...] ('Let the kings' sarcophagus rust in basements, / Let the stocks for rebel head rust in squares, / Let the chains from huge bridges rust in tunnels... // I just repeat: your yellowish house [...]'). However, the poems as well outline details that are useful for the ideological purposes: stressing the collectivism of the Soviet bloc countries, Hungarian children who give friendly hugs and burn one's cheeks with "moist kisses" and are whispering in an "incomprehensible language / Comprehensible words". Such references should make the uncomfortable theme of the anti-Soviet rebellion that was suppressed in 1956 in Hungary sink into oblivion, but still Vaičiūnaitè mentions "stocks for rebel head", which by obvious logical mistake (stocks for head) unconsciously display the replaced forbidden content. However, this final poem of the cycle with a dangerous hint was translated by the translator Leonidas Milius and published in 1962 in the republican newspaper Вечерние новости but was not included in the cycle; the chapter "Венгерские стихи” is gloriously ended by Sergeiev's fluently rhymed (no rhyme in the original) translation about the Danube cruise which is immune to the variety of images and the flow of author's mood.

The translation practice problems of the time were highlighted in the 1964 by the chairman deputy of the USSR Writers' Association, the writer and translator of prose and poetry, Nikolaj Čukovskij: a clear distortion of the original, the translators craftsmanship and sometimes easy additional income (Čukovskij 1964). Many works of art in literature have been translated by using 'the literal translation of the original and without having a deeper understanding of the source language. However, not only disadvantages have been disclosed: the existence of literary "slaves" (there were no such among the ones that prepared Vaičiūnaitè's collection), collaboration of translators with controlling institutions (this is marked by the propagandist content and additions in translations that were not present in the original). More generally 
BERNOTIENÉ

the propagandist-educational character of the translations of that time versus their artistic aims in Soviet literary criticism will be discussed later, after the revision of the Soviet period heritage, evaluating the role of literature as a servant for the Soviet power machine.

There are no ways to ascertain how the translation of Vaičiūnaitës book helped her in the poetic career. It says a lot that the poetess herself has not mentioned it publicly. The translations of the book have not been authorized, whereas other more influential poets supported by the government have followed such practice (e.g., Vacys Reimeris whose book was published by the same publishing house Молодая гвардия).

\section{Conclusions}

Vaičiūnaitè's collection Cmuxu was not accidental, but a favoured, ideologically constructed project that characteristically witnessed the state of poetry translations of the 1960s. Her sensitive, intimate poetry was attractive and handy for the compilers of the collection; it was a voice of the new generation that wass deviating from the compulsory ideology, flowing with intimacy and, thus, not so openly engaging and reliable. However, the mimicric strategy of soft, intimate ideology was disclosed by the ideological additions of translators that were not ashamed to distort the original and vividly demonstrate that the aesthetic value of the original and its translations for the publishing and propaganda industry of that time was of secondary importance.

The inaccurate and literal translations using the original in the most general sense, the militant pathos that changed Vaičiunnaitè's suppressions, the disproportion of the translator's and author's aesthetic qualifications were the typical examples of the 1960s translation practice that were overshadowed only a decade later by the improving quality of translations. Contrary to the post-structural translation theories that tend to generalise, identify ideological mechanisms with potential text intertextuality (Karoubi 2005), it is possible to view the treatment of translation and text authorship prevalent at the beginning of the 1960s in the Soviet Union as poetry being sacrificed to ideology and the text's meaning adapted to the new target audience according to the ideological requirements of a single political party. 
Intended Fallacies: Lowered Horizons, Ideological Inversions and Employed Intimacy

\author{
Gintarè Bernotienè \\ gintare.bernotiene@gmail.com \\ Šiuolaikinès literatūros skyrius \\ Lietuvių literatūros ir tautosakos institutas \\ Antakalnio g. 6 \\ LT-10308 Vilnius \\ LIETUVA / LITHUANIA
}

\title{
Bibliography
}

Čukovskij, N. 1964. Vysokoe iskusstvo. - Literaturnaja gazeta, 30.01. = Чуковский, Н. 1964. Высокое искусство. - Аитературная газета, 30.01.

Gjada, S. 1986. Uščerbnaja luna, osennjaja boginja: stihotvorenija i poèmy. Vil'njus: Vaga. = ГяАа, С. 1986. Ущербная муна, осенняя богиня: стихотворения и поэмы. Вимьнюс: Vaga.

Gjada, S. 1989. Skvorec pod lunoj: stihotvorenija i poèmy. Moskva: Sovetskij pisatel'. = ГяАа, С. 1989. Скворец под муной: стихотворения и поэмы. Москва: Советский писатемь.

[Editor's note.] 1960. - Ju. Vajčjunajte, Stihi. Moskva: Molodaja gvardija, [2]. = Ю. Вайчюнайте, Стихи. Москва: Молодая гвардия, 2.

Karoubi, B. 1960. Ideology and Translation. - http://www.translationdirectory.com/ article233.htm (201504 10).

Lefevere, A. 1992. Translation, Rewriting and the Manipulation of Literary Fame. London: New York (N. Y.), Routledge.

Martinajtis, M. 1981. Porog: stihi. [Perevod s litovskogo D. Samojlov i G. Efremov.] Vil'njus: Vaga. Мартинайтис, М. 1981. Порог: стихи. [ПеревоА с митовского A. Самойлов и Г. Ефремов.] Вимьнюс: Vaga.

Mitaitè, D. 2015. Sovietmečio literatų ryšiai. - Nevienareikšmés situacijos: Pokalbiai apie literatūros lauka sovietmečiu. Vilnius: Lietuvių literatūros ir tautosakos institutas, 100-102.

Nekrošjus, I. 1962. Melodii i pesni. - Sovetskaja Litva, 28 sentjabrja. = Некрошюс, И. 1962. Мелодии и песни. - Советская $\Lambda$ итва, 28 сентября.

Ogryzko, V. 2007. S čukotskogo na russkij. - Literaturnaja Rossija, 37. = Огрызко, B. 2007. С чукотского на русский. - Аитературная Poccus, 37, http://www. litrossia.ru/archive/item/2134-oldarchive (19.05.2016).

Samojlov, D. 1995. Pamjatnye zapiski. Moskva: Meždunarodnye otnošenija. = Самойлов, А. 1995. Памятные записки. Москва: Международные отношения.

Sokolov, V. D. 2006. Vladimir Sergeev. Udarennyj ottepel'ju. = Соколов, В. А. 2006. ВАаАимир Сергеев. УАаренный оттепелью. - http://www.webcitation. org/61CGtgpHF (16.03.2014). 
BERNOTIENÉ

Ten' solncа ... 1981. = Тень солниа: поэты Аитвы в переводах Аавида Самойлова (Альгимантас Балтакис, Валерия Вальсюнене, Альфонсас Малдонис, Мариемиюс Мартинайтис, Юстинас Мариинкявичюс, Эдуардас Межялайтис, Виниас Миколайтис-Путинас, Саломея Нерис). 1981. Вимьнюс: Vaga.

Vaičiūnaitè, J. 1952. Nekrasovui. - Jaunimo gretos, 5, 12.

Vajčjunajte, Ju. 1960. Teni na snegu. - Literaturnaja gazeta, 01.12. = Вайчюнайте, Ю. 1960. Тени на снегу. - Аитературнал газета, 01.12.

Vajčjunajte, Ju. 1962a. Dvadcat' millionov; Vosem' probilo. [Per. S. Kunjaeva.] Sovetskaja Litva, 28.09. = Вайчюнайте, Ю. 1962а. Авадцать мимлионов; Восемь пробимо. [Пер. С. Куняева.] - Советская Аитва, 28.09.

Vajčjunajte, Ju. 1962b. A s gor - predstaet gorod...; ... I ruki pahnut tak, kak - gruši... [Per. L. Milja.] - Večernie novosti, 04.12. = Вайчюнайте, Ю. 1962b. А с гор предстает город... ;... И руки пахнут так, как - груши... [Пер. А. Мимя.] Вечерние новости, 04.12

Vaičiūnaitè, J. 1963. Miestas - žvaigždèlapis. - Pergalè, 1, 73-75.

Vajčjunajte, Ju. 1964a. ... I mostovoju vremja rannee; ... A ja i ne znala, čto uločka est’ takaja. [Per. L. Milja.] - Komsomol'skaja pravda, 28.01. = Вайчюнайте, Ю. 1964а. ... И мостовою время раннее; ... А я и не знала, что улочка есть такая. [Пер. А. Мимя.] - Комсомольская правда, 28.01.

Vajčjunajte, Ju. 1964b. Probivšim gornuju dorogu; Svet. [Per. V. Sergeeva.] Literaturnaja gazeta, 30.01. = Вайчюнайте, Ю. 1964b. Пробившим горную Аорогу; Свет. [Пер. В. Сергеева.] - Аитературная газета, 30.01.

Vajčjunajte, Ju. 1964c. Ulica prostornaja. [Per. G. Gerasimova.] - Literaturnaja Rossija, 31.01. = Вайчюнайте, Ю. 1964c. УАица просторная. [Пер. Г. Герасимова.] - Аитературная Россия, 31.01.

Vajčjunajte, Ju. 1964d. Sosna. [Per. V. Sergeeva.] - Nedelja, 28.02. = Вайчюнайте, Ю. 1964d. Сосна. [Пер. В. Сергеева.] - Неделя, 28.02.

Vajčjunajte, Ju. 1964e. Starye Nagljaj. [Per. Ju. Kobrina.] - Komsomol'skaja pravda, 09.08. = Вайчюнайте, Ю. 1964е. Старые Нагляй. [Пер. Ю. Кобрина.] Комсомольскал правда, 09.08.

Vaičiūnaitè, J. 1992. Žvaigždè ant plonyčio stiebo. - A. Sabonis, S. Sabonis, eds., Rašytojas ir cenzūra: Straipsnių ir dokumentų rinkinys. Vilnius: Vaga, 194. 